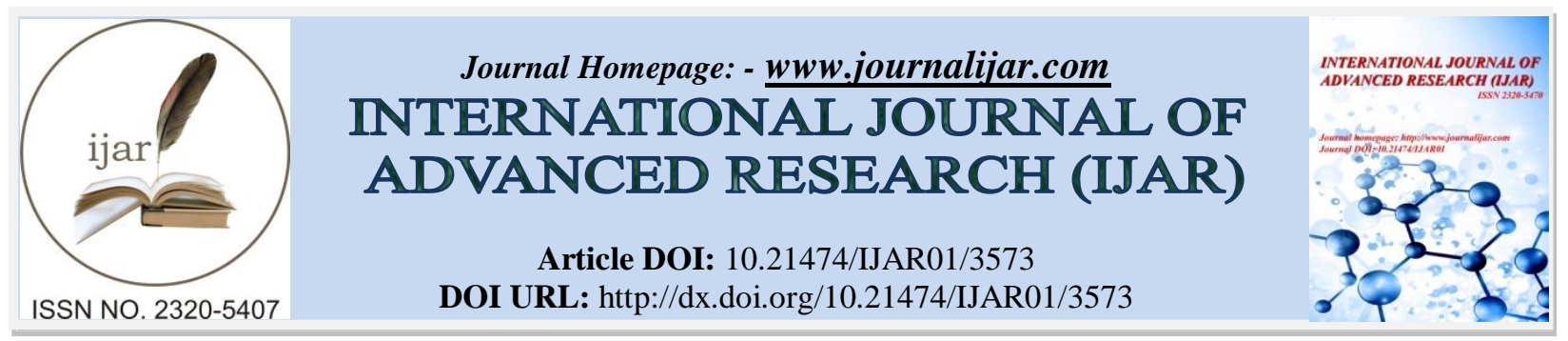

RESEARCH ARTICLE

\title{
PERFORMANCE OF GROWTH TRAITS IN BANDUR SHEEP UNDER FIELD CONDITION.
}

\author{
Siddalingamurthy H. $\mathrm{K}^{2^{*}}$, Manjunatha $S . \mathrm{S}^{3}$, Sreesujatha R.M ${ }^{1}$, Santhosh Talwar ${ }^{1}$, Remyashri B. $Y^{1}$ and \\ Namratha M. J'. \\ 1. Livestock Research and Information Centre (Sheep), Karnataka Veterinary Animal and Fisheries Sciences \\ University, Mandya district, Karnataka. \\ 2. Associate Professor and Head, Livestock Research and Information Centre (Sheep), Mandya district, Karnataka. \\ 3. Assistant Professor, Livestock Research and Information Centre (Sheep), Mandya district, Karnataka.
}

\section{Manuscript Info}

-.........................

Manuscript History

Received: 03 January 2017

Final Accepted: 09 February 2017

Published: March 2017

Key words:-

Bandur sheep, home tract, body weight, body measurement.

\section{Abstract}

Data pertaining to the body weight and body measurements of Bandur Sheep were collected on 737 animals from March 2015 to October 2015 of different age groups reared by farmers in the home tract village Bandur and its surrounding villages of Malavalli Taluk in Mandya district of Karnataka. The least squares mean body weight, height at withers, body length, chest girth and paunch girth were recorded to be $27.46 \pm 0.27 \mathrm{~kg}, 53.48 \pm 0.26,61.64 \pm 0.15,72.62 \pm 0.20$ and $74.99 \pm$ $0.23 \mathrm{~cm}$, respectively. All these traits were significantly affected by age and sex.

Copy Right, IJAR, 2017,. All rights reserved.

\section{Introduction:-}

Karnataka possesses well defined breeds of sheep such as Bandur, Decanni, Hassan, Bellary, Chitradurga, Yellaga and other local strain that are prevalent in certain parts of the state as adjunct to cropping pattern. Mandya sheep is the best mutton breed of sheep in India and is in great demand for upgrading of other native breeds for Mutton within the country and abroad (Arora and Acharaya, 1976, Rai et al., 1988). Mandya sheep is also called Bandur sheep because this breed is known to have originated from Bandur Village of Mallavalli taluk in Mandya district of Karnataka. Bandur sheep is the best mutton breed of the country and is being slaughtered regularly at high rate for mutton production leading to depletion in its number and genetic erosion over time lag. Hence, this warrants conservation and prolification of this breed. Data on production traits of Bandur sheep at the field condition is scanty. No systematic attempt has been made to study the production parameters of Bandur sheep under field conditions at farmer's flocks. In this context the present study was undertaken in Bandur sheep under field conditions with the objectives to quantify the performance traits such as body weights and body measurements and to study the effect of non-genetic factors on body weight and body measurements.

\section{Materials and Methods:-}

Data pertaining to the body weight and body measurements were recorded on 737 sheep reared by the farmers at different ages based on dentition. The above data was collected from March 2015 to October 2015 in the home tract area of Bandur sheep, Bandur village and its surrounding eighteen villages of Malavalli Taluk of Mandya district in Karnataka. The home tract of this breed is located at an altitude of $609.60 \mathrm{~m}$ above the mean sea level between the latitude $12.33^{\circ}$ and longitude $70.04^{0}$. The average rainfall of this area ranges from $518.9 \mathrm{~mm}$ to $897.4 \mathrm{~mm}$ over the last five years. The mean maximum daily temperature recorded was $35.2^{0}$ during April and a minimum was $17.2^{0} \mathrm{c}$ in December. The farmer's flocks were grazed from 10.00 am to $6.00 \mathrm{pm}$ on uncultivated waste land and other 
harvested fields. No supplemental feed is given to sheep maintained by the farmers. Lambs were allowed to suckle and remain with their mothers up to three months of age and weaned thereafter. Breeding rams were maintained under stall feeding conditions. Selective breeding was practiced in a limited way followed by flock mating system. Breeding is carried out throughout the year.

The animals were weighed using sensitive dial type (Salter) weighing balance before allowing for grazing and watering. Body measurements were recorded nearest to centimeter. All the measurements were taken using measuring tape after making the animal to stand squarely on an even surface. The animal was secured by an attendant with its head held a little high in a normal position as suggested by Turner et al., (1953) and measurements were taken. The whole operation was carried out by a single operator to minimize possible errors. The data on body weight and body measurements were classified into five age groups such as, milk teeth, two teeth, four teeth, six teeth and eight teeth groups. The pooled data again classified into two sex groups i.e. male and female.

The least squares mean and the standard error of various traits of growth were computed by adopting Harvey's least squares method of fitting constants using the mixed model least squares and maximum likelihood computer programme (Harvey, 1990). Data used in the present study comprised of unequal subclass frequencies, thus leading to non-orthogonality. To overcome non-orthogonality of data, the least square analysis of variance technique was adopted to detect the significant sources of non-genetic variation if any (Harvey, 1987). The following fixed model was used for analysis of body weight and body measurements,

$Y_{i j k}=\mu+A_{i}+S_{j}+e_{i j k}$

Where $\mathrm{Y}_{\mathrm{ijk}}=$ the record of the $\mathrm{k}^{\text {th }}$ individual belonging to the $\mathrm{i}^{\text {th }}$ age group and $\mathrm{j}^{\text {th }}$ sex group.

$\mu=$ population mean

$\mathrm{A}_{\mathrm{i}}=$ fixed effect of the $\mathrm{i}^{\text {th }}$ age group $(\mathrm{I}=1,2,3,4,5)$

$\mathrm{S}_{\mathrm{j}}=$ Fixed effect of $\mathrm{j}^{\text {th }}$ sex group $(\mathrm{j}=1,2)$

$\mathrm{E}_{\mathrm{ijk}}=$ Random error associated with $\mathrm{Y}_{\mathrm{ijk}}$ and assumed to be identically, independently and normally distributed with mean zero and the unit variance

\section{Result and Discussion:-}

The least squares mean along with their standard errors of body weight and body measurements at different ages and sex of Bandur sheep are presented in table 1. The overall least squares mean body weight of Bandur sheep was $27.46 \pm 0.27 \mathrm{~kg}$ (table 1). The mean body weight at different ages revealed that a faster growth rate from milk teeth to six teeth and the growth rate declined thereafter. This observation tallied closely with the reports of Acharaya and Bhat (1984) in Gaddi, Nagaraja et al. (1996), Siddalinga Murthy (2001) and vasundradevi (2013) in Bandur Sheep and Taye et al. (2010) in Washera Sheep. The effect of age on body weight was found to be significant. Significant difference in body weights due to age were also reported by Taneja et al. (1993) in Magra sheep and Swarnkar and Arora (1996) in Malpura sheep, Dayananda (1998) in Tumkur strain and Siddalinga Murthy (2001) in Bandur Sheep. The increase in body weight is being noticed with advancement of age might be due to physiological phenomena of growth.

The body weight recorded for males $(34.66 \pm 0.49 \mathrm{~kg})$ was higher compared to the females $(25.63 \pm 0.24 \mathrm{~kg})$ indicating sexual dimorphism with respect to growth. This observation confirms the reports of Singh and Mathur (1971) in Coimbatore breed, Nimbkar (1993) in Decanni breed, Taneja et al. (1993) in Magra breed, Taye et al. (2010) in Washera Sheep and Dayananda (1998) in Tumkur strain, Nayak et al. (2008) in Ganjam Sheep and Siddalinga Murthy (2001) in Bandur sheep. However, no significant difference in sex was reported by Singh and Singh (1974) in Bikaneri breed.

\section{Body measurements:-}

The least squares mean body measurements at different ages in Bandur sheep is shown in table.1.

\section{Height at withers:-}

The least squares mean of height at wither recorded $53.48 \pm 0.24 \mathrm{~cm}$ (Fig.3, table. 1). The present result was closely related with the values reported by Mahajan and Bahra (1977) in Gaddi, Taneja et al. (1993) in Magra, Dayananda (1998) in Tumkur strain, Taye et al. (2010) in Washera Sheep and Siddalinga Murthy (2001) and Vasundradevi (2013) in Bandur sheep. The height at withers of milk teeth group sheep differed significantly from all other age groups. Age had a Significant differences in height at withers as reported by Mahajan and Bahra (1977) in Gaddi, 
Taneja et al. (1993) in Magra, Dayananda (1998) in Tumkur stain and Siddalinga Murthy (2001) in Bandur sheep. In contrast, Basu Thakur and Negi (1967) in Rampur Bushair reported non-significant effect of age on height at wither. The variation in height at withers between age groups appears to be a normal physiological function. The height at withers recorded for males $(56.96 \pm 0.24 \mathrm{~cm})$ was higher compared to that of females $(52.51 \pm 0.11 \mathrm{~cm})$ and the difference was significant $(\mathrm{P} \leq 0.01)$. Similar observations were made by Nimbkar (1993) in Decanni, Taneja et al. (1993) in Magra, Dayananda (1998) in Tumkur strain, Nayak et al. (2008) in Ganjam Sheep, Taye et al. (2010) in Washera Sheep and Siddalinga Murthy (2001) and Vasundradevi (2013) in Bandur sheep.

\section{Body length:-}

The least squares mean of body length measured was $61.64 \pm 0.15 \mathrm{~cm}$ (Fig.2, table 1). The present result was similar to the reports of Nagaraja et al. (1996) in the same breed. The present observation was lower than the values reported by Basu thakur et al. (1967) in Rampur Bushair and Kalra et al. (1987) in Nali breed. However, body length recorded in the present study was higher than the values reported by Taneja et al. (1993) in Magra and Dayananda (1998) in Tumkur strain. Body length in milk teeth and two teeth age groups had significantly lower than all other age groups. The effect of age on body length was significant $(\mathrm{P} \leq 0.01)$. Significant differences in body length due to age were also reported by Taneja et al. (1993) in Magra, Dayananda (1998) in Tumkur strain and Taye et al. (2010) in Washera Sheep. The mean body length recorded for males was more $(63.70 \pm 0.27 \mathrm{~cm})$ compared to females $(59.54 \pm 0.13 \mathrm{~cm})$ and the difference was found to be significant. Similar reports were also made by Taneja $e t$ al. (1993) in Magra, Nayak et al. (2008) in Ganjam Sheep, Taye et al. (2010) in Washera Sheep and Siddalinga Murthy (2001) and Vasundradevi (2013) in Bandur Sheep. In contrast, Sharma et al. (1977) in Muzaffarnagari breed reported no significant effect of sex on body length.

\section{Chest girth:-}

The least squares mean chest girth recorded was $72.62 \pm 0.20 \mathrm{~cm}$ (Fig.1, table.2), which closely tallied with the values reported by Basu Thakur et al. (1967) in Gaddi, Kalra et al. (1987) in Nali and Siddalinga Murthy (2001) in Bandur sheep. The chest girth was lower than the values reported by Taneja et al. (1993) in Magra (80.03). However, the chest girth was higher than the values reported by Dayananda (1998) in Tumkur strain and Siddalinga Murthy (2001) in Bandur sheep. The chest girth of milk teeth and two teeth age groups varied significantly from other age groups. Significant differences in chest girth due to age were also reported by Taneja et al. (1993) in Magra, Dayananda (1998) in Tumkur strain, Taye et al. (2010) in Washera Sheep and Siddalinga Murthy (2001) in Bandur sheep. In contrast, Basu Thakar and Negi (1967) reported non-significant effect of age on chest girth in Rampur Bushair breed. The chest girth recorded for males $(76.42 \pm 0.41 \mathrm{~cm})$ was significantly $(\mathrm{P} \leq 0.01)$ higher than females $(71.43 \pm 0.19 \mathrm{~cm})$. Similar observations were made by Nimbkar (1993) in Deccani, Taneja et al. (1993) in Magra, Nayak et al. (2008) in Ganjam Sheep, Taye et al. (2010) in Washera Sheep and Siddalinga Murthy (2001) and Vasundradevi (2013) in Bandur sheep. In contrast, Dayanda (1998) in Tumkur strain, reported non-significant effect of sex on chest girth.

\section{Paunch girth:-}

The least squares mean paunch girth measured was $74.99 \pm 0.23 \mathrm{~cm}$ (Fig.4, table .1) which was tallied with the reports of Nagaraja et al. (1996) in Bandur breed. This value is lower than the values reported by Taneja et al. (1993) in Magra. However, it was higher than the value reported by Bhadula et al. (1979) in Muzzarffarnagari breed. The paunch girth of milk teeth and two teeth groups were lowest and differed significantly from those of remaining 4, 6, and 8 teeth age groups. Age had a significant effect on paunch girth which was in agreement with Taneja et al. (1993) in Magra, Dayananda (1998) in Tumkur strain and Siddalinga Murthy (2001) in Bandur sheep. The paunch girth recorded for males was more $(78.99 \pm 0.48 \mathrm{~cm})$ compared to the females $(73.78 \pm 0.23 \mathrm{~cm})$ and the difference was found to be highly significant $(\mathrm{P} \leq 0.01)$. Significant effect on paunch girth due to sex was also reported by Nimbkar (1993) in Decanni, Taneja et al. (1993) in Magra, Nayak et al. (2008) in Ganjam Sheep, Taye et al. (2010) in Washera Sheep and Siddalinga Murthy (2001) and Vasundradevi (2013) in Bandur sheep. However, Dayananda (1998) reported non-significant effect of sex on paunch girth in Tumkur strain.

\section{Conclusion:-}

The growth performance of Bandur sheep is quantified under field conditions in the home tract area. The study concludes that the Bandur sheep breed maintained by farmers under grazing system were equally efficient as those maintained at organized farms. Further the body weights and body measurements recorded in Bandur sheep were found similar to other recognized breeds found in southern peninsular India. 
Table.1:- Least squares means and standard error of body weight and body measurements at different ages of Bandur sheep.

\begin{tabular}{|l|c|c|c|c|c|c|}
\hline Particulars & $\begin{array}{c}\text { No. of } \\
\text { observations }\end{array}$ & $\begin{array}{c}\text { Body } \\
\text { weight(kg) }\end{array}$ & $\begin{array}{c}\text { Height at } \\
\text { withers }(\mathbf{c m})\end{array}$ & $\begin{array}{c}\text { Body length } \\
(\mathbf{c m})\end{array}$ & $\begin{array}{c}\text { Chest girth } \\
(\mathbf{c m})\end{array}$ & $\begin{array}{c}\text { Paunch girth } \\
(\mathbf{c m})\end{array}$ \\
\hline Overall & 737 & $27.46 \pm 0.27$ & $53.48 \pm 0.24$ & $61.64 \pm 0.15$ & $72.62 \pm 0.20$ & $74.99 \pm 0.23$ \\
\hline Age groups & & $\mathbf{0 . 0 1}$ & $\mathbf{0 . 0 1}$ & $\mathbf{0 . 0 1}$ & $\mathbf{0 . 0 1}$ & $\mathbf{0 . 0 1}$ \\
\hline $\begin{array}{l}\text { Milk teeth } \\
(1 \text { year })\end{array}$ & 116 & $23.76 \pm 0.57^{\mathrm{a}}$ & $51.79 \pm 0.27^{\mathrm{a}}$ & $56.91 \pm 0.29^{\mathrm{a}}$ & $68.73 \pm 0.45^{\mathrm{a}}$ & $70.66 \pm 0.55^{\mathrm{a}}$ \\
\hline $\begin{array}{l}\text { Two teeth } \\
\left(1_{1 / 2} \text { year) }\right.\end{array}$ & 169 & $27.99 \pm 0.46^{\mathrm{b}}$ & $54.14 \pm 0.21^{\mathrm{b}}$ & $60.18 \pm 0.23^{\mathrm{b}}$ & $72.15 \pm 0.33^{\mathrm{b}}$ & $74.52 \pm 0.47^{\mathrm{b}}$ \\
\hline $\begin{array}{l}\text { Four teeth } \\
\left(2_{1 / 2} \text { year) }\right.\end{array}$ & 120 & $32.97 \pm 0.49^{\mathrm{c}}$ & $54.21 \pm 0.24^{\mathrm{c}}$ & $62.85 \pm 0.27^{\mathrm{c}}$ & $75.74 \pm 0.43^{\mathrm{c}}$ & $78.60 \pm 0.51^{\mathrm{c}}$ \\
\hline $\begin{array}{l}\text { Six teeth } \\
\left(3_{1 / 2} \text { year) }\right.\end{array}$ & 144 & $33.46 \pm 0.51^{\mathrm{c}}$ & $56.19 \pm 0.22^{\mathrm{d}}$ & $64.47 \pm 0.26^{\mathrm{c}}$ & $76.49 \pm 0.41^{\mathrm{c}}$ & $79.23 \pm 0.50^{\mathrm{d}}$ \\
\hline $\begin{array}{l}\text { Eight teeth } \\
\left(4_{1 / 2} \text { year) }\right.\end{array}$ & 198 & $31.64 \pm 0.46^{\mathrm{d}}$ & $56.39 \pm 0.21^{\mathrm{d}}$ & $63.63 \pm 0.24^{\mathrm{c}}$ & $76.57 \pm 0.36^{\mathrm{c}}$ & $78.94 \pm 0.43^{\mathrm{d}}$ \\
\hline Sex & & $\mathbf{0 . 0 1}$ & $\mathbf{0 . 0 1}$ & $\mathbf{0 . 0 1}$ & $\mathbf{0 . 0 1}$ & $\mathbf{0 . 0 1}$ \\
\hline Male & 120 & $34.66 \pm 0.49^{\mathrm{a}}$ & $56.96 \pm 0.24^{\mathrm{a}}$ & $63.70 \pm 0.27^{\mathrm{a}}$ & $76.42 \pm 0.41^{\mathrm{a}}$ & $78.99 \pm 0.48^{\mathrm{a}}$ \\
\hline Female & 617 & $25.51 \pm 0.24^{\mathrm{b}}$ & $52.51 \pm 0.11^{\mathrm{b}}$ & $59.54 \pm 0.13^{\mathrm{b}}$ & $71.43 \pm 0.19^{\mathrm{b}}$ & $73.78 \pm 0.23^{\mathrm{b}}$ \\
\hline
\end{tabular}

Within the column means with at least one common superscript do not differ significantly from each other.

\section{References:-}

1. Acharya, R.M. and Bhat, P.N. (1984): Livestock and poultry genetic resources in India. Publication and Information Section. Indian Veterinary Research Institute, India.

2. Arora, C.L. and Acharya, R.M. (1976): Improvement of Mandya sheep in Karnataka: A review. Indian J. Anim. Sci., 46: 340-345.

3. Basu Thakur, A.K. and Negi, G.C. (1967): A study of phenotypic biometry of indigenous Rampur Bushair sheep. Indian J. Vet. Sci., 38: 258-261.

4. Basu Thakur, A.K., Mahajan, J.M. and Singh, O.N. (1967): A study on body weight and confirmation of Gaddi and Romney Marsh sheep. Indian Vet. J., 44: 589-595.

5. Bhadula, S. K., Bhat, P.N. and Garg, R.C. (1979): Prediction of body weight from body measurements in sheep. Indian J. Anim. Sci., 49(10): 775-777.

6. Dayananda, N.G. (1998): Evaluation of local strain of sheep in Tumkur district of Karnataka for economic traits. M.V. Sc. Thesis, Univ. Agric. Sci., Bangalore.

7. Harvey, W.R. (1987): Least squares analysis of data with unequal subclass numbers, ARS, USDA.

8. Harvey, W.R. (1990): User's guide for lsmlmw and mixmdlpc-2 version, mixed model least squares and maximum likelihood computer programme.

9. Kalra, S., Singh, B. and Arora, D.N. (1987): Body confirmation of Nali sheep - a note. Indian J. Anim. Prod. Mangt., 2(4): 136-164.

10. Mahajan, J.M. and Bahra, S.D.J. (1977): Some biometrical investigations in the Gaddi hill breed of sheep. Indian J. Anim. Res., 11(1): 44-48.

11. Nagaraja, C.S., Govindaiah, M.G., JayaShankar, M.R. and Krishnappa, S.B. (1996): Prediction of body weights from body measurements in Bandur sheep. Curr. Res., 25: 211-212.

12. Nayak, S., Sahu, G and Mohapatra, A.K. (2008): Study on management practices, phenotypic and reproductive characteristics of Ganjam sheep under range conditions of Orissa. SAARC Jn. of Agri., 6(2).

13. Nimbkar, C. (1993): The goats and sheep of the Deccan plateau in Maharashtra state of India. Anim. Genetic Resources Inform., 12: 81-91.

14. Rai, A.V., Desai, D.S., and Rao, H.K.R. (1988): Performance of Mandya sheep. Curr. Res., 8(1); 11-12.

15. Sharma, S.K., Bhat, P.P., Bhat, P.N. and Garg, K.C. (1977): Effects of genetic and non-genetic factors on preweaning body measurements in Muzaffarnagari breed of sheep and its crosses with Corriedale. Indian J. Anim. Sci., 47: 529-533.

16. Siddalinga Murthy, H. K. (2001): Evaluation of Bandur sheep in Mandya district of Karnataka for economic traits. M. V. Sc. Thesis submitted to UAS, Bangalore.

17. Singh, V.K. and Mathur, P.B. (1971): Studies on body measurements indicating mutton production. Indian Vet. J., 48: 629-634. 
18. Singh, B.P. and Singh, M.R. (1974): Relative importance of body measurements for body weight and wool yield of Bikaneri lambs. Indian J. Anim. Hlth., 13: 37-40.

19. Swarnkar, C.P. and Arora, A.L. (1996): Monthly variation in adult body weights of ewes under semi-arid conditions of Rajastan. Indian J. Small Ruminants., 2(1): 1-6.

20. Taneja, A.D., Yadav, S.B.S., Sharma, B.S. and Pant, K.P. (1993): Body dimension of Magra sheep in farmers flock. Indian J. anim. Sci., 63(6): 681-683.

21. Taye Mengistie, Abebe Girma, Gizaw Solomon, Lemma Sisay, Mekoya Abebe and Tibbo Markos. (2010): Traditional management systems and linear body measurements of Washera sheep in the western highlands of the Amhara National Regional State, Ethiopia. Livestock Research for Rural Development. 22 (9).

22. Turner, H.N., Hayman, R.H., Rickes, J.H., Roberts, N.F. and Wilson, L.T. (1953): Physical definition of sheep and their fleece for breeding and husbandry studies. Division of animal health and production, CSIRO, Melbourne, Australia.

23. Vasundradevi, M. (2013): Gentic evaluation of Bandur sheep under field conditions. P.hD., Thesis submitted to Karnataka Veterinary Animal and Fisheries Sciences University, Bangalore. 